Anna Gallewicz (Warsaw)

\title{
Urbino and Prądnik: Two Courts, Two Worlds
}

Having decided to present the ideal courtier, Górnicki could easily give up an idea of Castiglione, who presents his reflections in the form of dialogue, and make his own work in the form of treatise. Yet, he decides to follow the idea of the Italian author and chooses a dialogue, and open and flexible literary form, making it easy to present different points of view without the necessity to reach irrefutable conclusions, while at the same time allowing for the author to remain neutral. This would suggest that also the Polish author did not want his text, like the Italian composition, appear to the readers too direct and too categorically didactic. ${ }^{1}$ The dialogue, however, was the form very esteemed by writers of the Renaissance period. Its popularity mirrored the open mentality of the era which followed the Middle Ages, indicated a new critical attitude, rejecting the rigid and dogmatic approach of the scholastic medieval period, conscious problematicity and relativity of things. ${ }^{2}$ In Poland, its $16^{\text {th }}$ century shape was influenced by two traditions: the ancient dialogue in prose and metrical medieval dialogue; this for was often used to present political, social and religious arguments. ${ }^{3}$

Górnicki adopts not only Castiglione's idea of dialogue, but also follows the technique chosen by the Italian author: the Dworzanin polski (The Polish Courtier) is a diegetic dialogue. ${ }^{4}$ The author situates the action of

1 See E. Saccone, Le buone e le cattive maniere. Letteratura e galateo nel Cinquecento, Bologna, 1992, p. 67.

2 O. Zorzi Pugliese, Il discorso labirintico del dialogo rinascimentale, Rome 1995, pp. $10-11$.

3 J. Ziomek, Literatura odrodzenia, Warsaw, 1987, p. 60.

4 Following Plato, theoreticians of the Renaissance era distinguish between three types of the dialogue: mimetic, diegetic and mixed dialogue. 
his work within a specific concrete social reality, determines the place, circumstances and characters who, significantly, are not only types but also images of actual persons. Such a measure allows us to assume that the intention of the Polish author was not only to present various points of view in order to construct the image of the perfect courtier, but also to demonstrate who was to play that important role. Thus, the diegetic technique made it possible for the author to shift attention from the word to the context in which it was uttered: ${ }^{5}$ a narrative 'frame' and 'scene' on which a dialogue was held were in this way becoming an integral part of the argumentative strategy of the text.

Górnicki, as the only European writer of the Renaissance era from among those who were interested in Castiglione's work, creates his own narrative frame, treating the Italian original only as a model. His predecessors: Spaniard Juan Boscan, Frenchman J. (Jacques?) Colin, Englishman Sir Thomas Hoby and finally Germans Laurentz Kratzer and Johannes Turler do not interfere with the represented world of the Italian original and faithfully translate Castiglione's text. ${ }^{6}$ This original approach of the Polish author would suggest that Górnicki did not want to be the translator of Il Libro del Cortegiano, but he preferred an emulative and adaptive method; the Italian text was to serve him as the source of ideas. What's more, the fact that Górnicki created his own conception of the narrative frame indicates that he was the only one to correctly understand and interpret its role within the Italian work. Locating the action in a specific reality and authoritativeness of presented characters have much reinforced the effect of his dialogue. Thus, the 'frame' was not to be a passive description of the selected community, but also a carrier of important messages. Characters present themselves as living exempta of the model which they propose. The introduction of a Polish society, and above all of Polish interlocutors (there are to be found in the Dworzanin also realistic representations of historical personages well-known to contemporary Polish readers) allows the narrative 'frame' to preserve this comprehensive role assigned to it by the Italian author. Yet, Górnicki's decision to adopt Castiglione's conception ran a certain risk. And as much as 'conversational plays' were very popular

5 P. Floriani, 'Il dialogo e la corte nel Primo Cinquecento', in: La corte e Il Cortegiano, ed. by C. Ossola and A. Prosperi, Rome, 1980, vol. 1, p. 91.

6 Cf. P. Burke, The fortunes of the Courtier, Cambridge, 1995 (Ital. transl. A. Merlino, Rome, 1998, p. 63). 
in countries of Western Europe, they were rather rare in Poland. The art of conversation with the participation of all present people was defeated by the art of narration. It was the skill of story-telling that was very much appreciated by contemporary Poles and was an important part of their lives. Since, Górnicki's position was not an easy one, he could not ignore the fact that his idea to present a 'conversational play' might seem bizarre to his readers who spent their evenings amusing themselves by telling stories and not by conversing. ${ }^{7}$ At the same time, the question then arises whether the changes introduced by the Polish author are of 'superficial' character only or do they interfere in the ideological level of the Italian text?

A group of interlocutors presented at Prądnik is much less numerous than the group debating at Urbino, also the diversity of characters is smaller. In the Italian text, in the chamber of Duchess Elisabetta Gonzaga there are present both the representatives of the elites of that time:

Emonge whych (as you knowe) were moste famous the Lord Octavian Fregoso, Sir Friderick his brother, the L. Julian de Medicis, M. Peter Bembo, the L. Cesar Gonzaga, Count Lewis of Canossa, the L. Gaspar Pallavicin, the L. Lodovicus Pius $[\ldots] .^{8}$

and the characters whose function was to emphasise only a playful nature of the meeting: jester Frier Seraphin, poet Unico Aretino, sculptor Johnchristopher Romano, musician Terpander and expert in the knightly arts, maestro Peter Mount, but without whom the picture of the court at Urbino would be incomplete. A description of how similar evenings are organised at the court of Urbino, which in the Italian text appears in

7 Cf. H. Dziechcińska, Literatura i zabawa, Warsaw, 1981, pp. 24-25; W. Łoziński, Zycie polskie w dawnych wiekach, Cracow, 1964, p. 170.

8 B. Castiglione, The Book of the Courtier, transl. by Sir Thomas Hoby in 1561 and ed. by Walter Raleigh for David Nutt, Publisher, London, 1900, p. 33 (all English quotations, together with the names of the characters are from this edition - note of the transl.). In Italian: B. Castiglione, Il libro del Cortegiano, ed. by W. Barberis, Turin, 1998, pp. 23-24: 'celeberrimi il signor Ottaviano Fregoso, messer Federico suo fratello, il Magnifico Iuliano de’ Medici, messer Pietro Bembo, messer Cesar Gonzaga, il conte Ludovico da Canossa, il signor Gaspar Pallavicino, il signor Ludovico Pio.' (all Italian quotation are from this edition). 
three chapters of the Book One (IV, V, VI), testifies, on the one hand, how important was for Castiglione to present, almost in chronicler's manner, a typical courtly event, while on the other it demonstrates that the very intention to present the perfect courtier did not differ in any way from other "plays' in Urbino. At Prądnik, however, the suggestion of Bishop Maciejowski seems to be a novelty and is not rooted in the tradition of such gatherings; this is a possible situation, but not very probable:

[...] trefiło sie raz, iż ksiądz biskup, po obiedzie u stołu siedząc [...], gdy ktoś karty wspomniał, powiedział: - Azaby się nie mogła naleźć jaka ina krotochwila, nie ta ustawiczna - karty? Czemuby też nie kto wniósł owego obyczaju do nas, który jest we Włoszech, iż szlachta zacna [...] wynajduje na biesiedzie gry rozumne i tych używa $[\ldots] .{ }^{9}$

There is no place in the Polish text for those characters whose role could be reduced to the ludic function. At Prądnik, it is a meeting of equals; this gathering of equals, who are literary representations of outstanding personages of the Polish court circle, is not only to describe the ideal courtier but also, by its eminence, to ennoble this status (or, according to Castiglione, profession) in the eye of readers. Thus, who are those chosen by the author as worthy representatives of the courtly circle? Among nine presented characters, there are courtiers of Samuel Maciejowski: Andrzej Kostka and Lupa Podlowski. There is also the Bishop's brother Castellan of Lublin Stanisław Maciejowski, and several courtiers at the royal court: Wojciech Kryski, Stanisław Wapowski, Aleksander Myszkowski, Jan Derśniak and Stanisław Bojanowski. Górnicki resigns almost totally from introducing into his story supporting or minors characters. He mentions them only at the beginning of the Book Two. ${ }^{10}$ This decision would suggest that it was not the description of the courtly circle that was the most important for the Polish author. Thus, we deal here with one of most significant differences between the two texts. It does not seem to be accidental, since in all these instances where Castiglione devotes much place to present Urbino,

9 Ł. Górnicki, Dworzanin polski, ed. by R. Pollak, Wrocław, 1954, p. 24 ('[...] it happened once that Father Bishop, while sitting at the dinner table [...] after someone had mentioned playing cards, said: - Whether it is not possible to find another entertainment instead of this constant one - cards? Why no-one could bring in this custom of the righteous Italian nobility [...] who devise thinking games at feasts and plays them [...]'). 10 Górnicki, Dworzanin polski, pp. 125-126: 'Zeszło się ku tej rozmowie coś więcej niż przedtem dworzan i inych zacnych ludzi' (This discussion attracted a bit more courtiers and other respectable people than before). 
Górnicki only apparently imitates the Italian author; his descriptions are devoid of the sophistication and minuteness characteristic of Cortegiano. It is evident already at the beginning of the two texts, when both authors present for the first time the place of action and circumstances which had brought the characters together. As much as Castiglione describes the vicinities of Urbino in great detail, attaching importance to each detail and in consequence almost mythycising presented places, Górnicki describes the reality interesting for him in a succinct and simple way. A tendency to resign from poetic embellishments of narrative parts is evident also in other fragments of the Polish text. Let us illustrate it on the example of closing fragments of the two texts:

Co gdy sie wszytkim podobało, zaraz powstawszy jedni do Jego Miłości księdza biskupa, drudzy do ogroda na przechadzkę poszli. (Górnicki) ${ }^{11^{*}}$

Whan the windowes then were opened on the side of the Palaice that hath his prospect toward the high top of Mount Catri, they saw alredie risen in the East a faire morninge like unto the colour of roses, and all sterres voided, savinge onelye the sweete Governesse of the heaven, Venus, whiche keapeth the boundes of the nyght and the day, from whiche appeered to blowe a sweete blast, that filling the aer with a bytinge cold, begane to quicken the tunable notes of the prety birdes, emong the hushing woodes of the hilles at hande. ${ }^{12}$ (Castiglione)

Similarly, it was not on any special occasion that the Polish courtiers meet at the court of Maciejowski:

Rychło tedy potym kiedy Król Jego Mość po śmierci króla Zygmunta, świętej pamięci ojca swego, na regiment królestwa polskiego wstąpił i do Krakowa przyjechał, ksiądz Maciejowski prze nie barzo sposobne zdrowie na Prądnik odjechawszy, siedm albo ośm dni tam mieszkał. A gdy do niego często dworzanie, pan Kryski, pan Wapowski, pan Aleksander Myszkowski, pan Derśniak, pan Bojanowski i ini zacni przyjeżdżali, trefiło się raz $[\ldots] .^{13}$

11 *After it pleased all, they prompty went out, some to His Grace Father Bishop, others to the garden for a stroll.

12 Ibid., p. 501; Castiglione, Book of the Courtier, p. 365 (in Italian: p. 441: 'Aperte adunque le finestre da quella banda del palazzo che riguarda l'alta cima del monte di Catri, videro già esser nata in oriente una bella aurora di color di rose e tutte le stelle sparite, fuor che la dolce governatrice del ciel' di Venere, che della notte e del giorno tiene i confini; dalla quai parea che spirasse un'aura soave, che di mordente fresco empiendo l'aria, cominciava tra le mormoranti selve de' colli vicini a risvegliar dolci concerti dei vaghi augelli.').

13 Górnicki, Dworzanin polski, pp. 23-24 ('Soon after His Majesty the King after the death of King Sigismund, his late lamented father, ascended the regiment of the 
Thus, also in this place Górnicki differs from the original in which the splendour of the place corresponds to the importance of the moment: at Urbino it was the visit of Pope Julius II at the court of duke and duchess da Montefeltro, who received him "as honorably as was possible, and with as sumptuous and costlye preparation, as coulde have bine in any other Citie of Italy whatsoever it be.' Castiglione chooses his characters from among the participants of this event: "for vertue verie singular." 14

Omitting the elements that would testify to the originality of described events, Górnicki takes on, or even more, puts in the forefront, another aspect of Castiglione's description: the role played by the court of Urbino in Renaissance Italy. Thus, in the Polish text the exceptionality of Prądnik is emphasised, which thanks to the Bishop was to be a forge of talents:

[...] miał [Maciejowski] zawżdy około siebie zacne, uczone i dzielne ludzi, na co kosztu ani starania nie litował, garnąc takie ku sobie i wielkimi jurgielty wzywając, tak iż dwór jego był jedną osobną szkolą rycerskich ludzi, z któremi żył nie jako pan ze sługami, ale jako ociec z syny.

Ale nie to jest rzecz przedsięwzięcia mego wyliczać te, którzy z księdza Maciejowskiego szkoły ku wysokim stolicam i dostojeństwu przyszli; to telko powiem, iż z onego trojańskiego konia nie wyszło nigdy tak wiele mężnych żołnierzów, jako z domu księdza Maciejowskiego dobrych, cnotliwych i godnych ludzi. ${ }^{15}$

Polish Kingdom and arrived in Cracow, Father Maciejowski suffering ill health left for Prądnik, and remained there for seven or eight days. And when he was frequently visited by courtiers, Sire Kryski, Sire Wapowski, Sire Aleksander Myszkowski, Sire Dereśniak, Sire Bojanowski and other respectable, it happened once [...]').

14 Castiglione, Book of the Courtier, pp. 34, 294 (in Italian: pp. 26, 354: 'con quel piú magnifico e splendido apparato che si avesse potuto fare in qualsivoglia altra nobil città d'Italia'; 'omini per virtù singolari.').

15 Górnicki, Dworzanin polski, pp. 21, 23 ('[...] was [Maciejowski] always sourrounded by respectable, learned and brave people, on which he stinted neither money nor efforts, drawing them and attracting by great renumerations so that his court was a whole individual school of knightly people with whom he lived not like a lord with his servants but like a father with his sons. But it is not the purpose of my undertaking to list those who left Father Maciejowski's school for all capital cities and dignities; thus I will say only that there never emerged from that Trojan horse so many brave soldiers as there have come good, virtuous and worthy people from the house of Father Maciejowski'). Prises of the Bishop, however, are not Górnicki's original idea, because they are modelled on the Italian text: 'he [Guidubaldo] sett hys delyte above all thynges to have hys house furnished with most noble and valyaunte Gentylmen, wyth whom he lyved very famylyarly.' (p. 30); 'sopra ogni altra cosa procurava che la casa fusse di nobilissimi e valorosi gentiluomini piena, coi quali molto familiarmente viveva [...].' (p. 21). 'These men therfore, had they lived, I beleave would have come to that passe, 
A motivation for such a perspective seems to be easily explained: since at Maciejowski's court the most precious Polish mind were being shaped, also the thoughts expressed during a casual meeting were worthy of consideration.

For Górnicki, Prądnik was not the only court in Poland that merited to be glorified, and probably it could not be such, for a political situation in Poland was different than in Italy. During the presentation of the last 'conversational play' the author prised not the bihop's court but that of the king:

[...] tedy tak powiedam, iż kto by chciał chwalić dwór dzisiejszego pana, Króla JM. (nie wspominając jeszcze samego cnót i osobnych a prawie królewskich przymiotów), mógłby to bez pochlebstwa powiedzieć, iż u żadnego krześcijańskiego króla tak wiele czystych ludzi na kupie nie najdzie, a którzy by, mimo rycerskie główne rzemięslo, tak ćwiczeni w rozmaitych rzeczach byli, jako na dworze teraz Pana naszego. ${ }^{16}$

It was probably for this reason that the resigns from a detailed description of the court community at Prądnik, thus straying away from the

that unto whoso had knowen them, they woulde have showed a manifest proof, how much the Court of Urbin was worthie to be commended, and howe fournished it was with noble knightes, the whiche (in a maner) all the rest have done that were brought up in it. For trulye there never issued out of the horse of Troy so many great men and capitaines, as there have come menne out of this house for vertue verie singular and in great estimation with al men' (p. 294); 'Questi adunque se vivuti fossero, penso che sariano giunti a grado, che ariano ad ognuno che conosciuti gli avesse potuto dimostrar chiaro argumento, quanto la corte d'Urbino fosse degna di laude e come di nobili cavalieri ornata; il che fatto hanno quasi tutti gli altri, che in essa creati si sono; ché veramente del caval troiano non uscirono tanti signori e capitani, quanti di questa casa usciti sono omini per virtù singulari e da ognuno sommamente pregiati.' (p. 355). 16 Górnicki, Dworzanin polski, p. 37 ('[...] then, I say this, that if anyone wants to praise the court of our Lord, His Majesty the King (not to mention his virtues and truly kingly attributes), he could say without flattery that nowhere at any other Christian king would he find so many upright gentlemen who besides their principal profession of chivalry are so worthy in soundry things as those at the court of our Lord). Also here Górnicki repeats Castiglione's expressions, but for a different purpose: 'who so woulde take in hande to praise oure Court [...] For peradventure in all Italy a man shall have muche a do to fynde out so many gentlemen and noble personages that are so worthy, and besyde the principall profession of Chivalrye so excellent in sundry thinges, as are presently here.' ('dico che chi volesse laudar la corte nostra [...], ben poria senza suspetto d'adulazion dir che in tutta la Italia forse con fatica si ritrovariano altrettanti cavalieri cosi singulari, ed oltre alla principal profession della cavalleria cosi eccellenti in diverse cose, come or qui si ritrovano', p. 35). 
Italian original in which the world of Urbino is presented on two levels: on the one hand it is created by characters participating in the discussion, while on the other its image is pained by words of those people. Thus, these fragments in which Castiglione lists individual people from the court in Urbino are either omitted in the Polish text, ${ }^{17}$ or are of a very general character:

A kto się nie musi śmiać, kiedy owo kto [...] jakoby kij połknął tańcuje? ${ }^{18^{*}}(\mathrm{G}$.) Which of you is it that laugheth not whan our M. Peterpaul daunseth after his owne facion, with such fine skippes and on tipto without moving his head, as though he were all of wood $[\ldots] ?^{19}(\mathrm{C}$.)

Yet, it happens that Górnicki, like Castiglione, supports his discourse by concrete examples:

Ale jądro tej trefności a wdzięczność wszytka w tym jest, aby człowiek powiedając, jako sie rzecz w sobie miała, umiał wyrazić twarz, słowa, obyczaje i sprawę wszytkę tego, o kim mówi, iżby ci, którzy słuchać będą, zapomniawszy sie mnimali, że to przed oczyma ich teraz się dzieje. I kto w to może dobrze potrefić, z nie bardzo trefnej rzeczy barzo trefną uczyni. Jako to na schwał dobrze umie Jego MPan grabia z Tarnowa, kasztelan krakowski [...]. (G.)

But the perfect grace and very pith of this, is to set furth so well and without peine not onlie in woordes but in gestures, the thynge a man pourposeth to expresse, that unto the hearers he maye appeere to do before their eyes the thinges he speaketh of. [...] wherin hitherto I have seene none passe oure M. Robert of Bari [one of the people present]..$^{20}(\mathrm{C}$.)

There is, however, a significant difference to be seen between these fragments: the Italian version mentions a personage belonging to the court of Urbino while Górnicki seems not to pay any attention to the fact that the person mentioned by him does not belong to the court of Bishop Maciejowski. Thus, in the Dworzanin, unlike in Cortegiano,

17 Górnicki, Dworzanin polski, pp. 50, 74, 105, 138.

$18{ }^{*}$ And which of you will not laugh when someone [...] danceth stiff as a ramrod?

19 Górnicki, Dworzanin polski, p. 70; Castiglione, Book of the Courtier, p. 59 ('Qual di voi non ride, quando il nostro inesser Pierpaulo danza alla foggia sua?', p. 60).

20 Górnicki, Dworzanin polski, p. 206; Castiglione, Book of the Courtier, pp. 160-161 ('Ma la grazia perfetta e vera virtù di questo è il dimostrar tanto bene e senza fatica, cosi coi gesti come con le parole, quello che l'omo vole esprimere che a quelli che odono paia vedersi inanzi agli occhi far le cose che si narrano. [...] nella quai cosa fin qui non ho veduto alcuno piú eccellente di messer Roberto nostro da Bari.' pp. 189-190). 
where the interlocutors allude to a real people associated with the court of the Montefeltro princes, Górnicki's allusions are most often of general character and on these are occasions when concrete names are mentioned, they do not belong to the Bishop's residence at Prądnik. What is also significant is that it is only on very rare occasion that the Polish author uses the possessive pronoun 'our' which in the Italian text almost always accompanies described people and which strengthen not only the impression of probability of the described event but also of the integrated community of the court of Urbino, almost family-like. Therefore, as much as Castiglione, according to the principles set forth in the Dedicatoria, presents his own world, the world which is different and distant from any other possible world, it seems that Górnicki does not want to paint a verbal picture of Prądnik. In consequence, in his introduction to the Book One, he omits Castiglione's words: "I send unto you this booke, as a purtraict in peinctinge [...]', ${ }^{21}$ and then simplifies or omits these idyllic painterly elements which are characteristic of the Italian original. But in all the places where the Italian author describes the persons who are to 'make up' the ideal courtier, Górnicki always tries to treat Cortegiano as the model to follow. And not only in the initial part of the text, but also in the beginning of the Book Three (pp. 293-294 and 255-256) and Four (pp. 391-395 and 353-356). Thus, if the Polish author did not intend to paint a 'verbal' portrait of the court, we are justified in thinking that he espoused Castiglione's idea to commemorate outstanding figures of the era:

Tym też kstałtem każdy mądry obaczyć z tej trochy słów może, co to był za człowiek Maciejowski, którym sie tak wielcy ludzie bawili [...]. Wiem pewnie, że mi ich godność i osobne przymioty wielka część Polski przyzna. I tego mi żaden za złe mieć nie będzie, iż tym, którym śmierć słusznie przepuścić miała, nieśmiertelnej sławy pragnę, a ile mogę światu a przyszłemu potomstwu one oznajmuję, aby tak w pamięci ludzkiej zawdy żyli.22 $23^{*}$

21 Castiglione, Book of the Courtier, p. 17 ('[...] mandovi questo libro come un ritratto di pittura [...]', p. 7)

22 Górnicki, Dworzanin polski, p. 293.

23 * In this way, each wise head can see from these few words what a man was this Maciejowski, with whom such great people were playing [...]. I know that a great part of Poland will admit that I am right about their dignity and virtues. And nobody will hold against me that I want immortal fame for them and as much as I can I will try to imprint them in people's memory. 
The central figure of the meeting at Prądnik is, of course, the host, Bishop Samuel Maciejowski. Górnicki bases his protagonist on two characters presented by Castiglione. In part, Maciejowski corresponds to Duke Montefeltro and for this reason he de facto does not participate in the discussion. Guidobaldo does not take part in the evening conversations for his poor health, on the one hand his absence, and thus the absence of Bishop in the discussion of the ideal courtier has its pragmatic explanation: as one of the addressees of the text (which is evident mainly in the Book Four describing the relationship between the ruler and the courtier) they cannot contribute to the discussion since it would restrict the freedom of interlocutors. For this reason Górnicki makes Maciejowski to leave the scene for good before the conversation begins:

[...] przyszło pacholę dając znać, iż komornik z listy od Króla JM. przyjechał; które listy gdy ksiądz biskup wzią i przeczedł, iż sie wielkie rzeczy (jako to potym tajno nie było) w nich zamykały, zaraz wstać a dla odprawy ich do kownaty [...] iść musiał. ${ }^{2425^{*}}$

In part, on the other hand, in these rare moments when Maciejowski is still present during the discussion, he takes on the role of Duchess Elisabetta, that is the character who dominates the meetings. His way of 'leading' the group of debaters, however, is quite different from what Castiglione proposes. The duchess' relations with the people who surround her are without severity and distance; her attitude is characterised by an exceptional naturalness towards others, despite her special high position at the court. This is evident in the duchess' reactions to some remarks about her person: she takes Unico Aretino's words with a good grace; they are playful and express commitment, yet a bit malicious:

24 Ibid., p. 30; cf. also: 'Gdy było nazajutrz po obiedzie, ksiądz biskup dla spraw Króla JM. musiał na pokój odyść [...]', p. 125. 'Kiedy do trzeciej namienionej rozmowy przyszło, ksiądz biskup po obiedzie, chcąc się troszkę przespać, odszedł na pokój [...]', p. 294. 'W godzinę potym abo trochę później, po obiedzie (kiedy już był ksiądz biskup na pokój odszedt) [...]', p. 396.

$25^{*}[. .$.$] a page entered to say that letters from the King had arrived; and when the$ Bishop took the letters and read them, he had to go to his chamber to reply to them for they contained important matters (as it became obvious later). 
I (quoth he) would gladlye be a judge of aucthoritye that I might with all kinde of tourment bolte out the truth of offenders: and that, to discover the deceytes of an ungrate woman, who with the eies of an angel, and hearte of a Serpent, never agreeth her tunge with her mynde [...]. Neither is there in all the sandie countrey of Libia to be found so venemous a serpent that is so deirous of mans bloud, as is this false creature. ${ }^{26}$

The passage quoted above testifies that in 16-century Italian courtly society such puns and allusions were fully accepted and were quite frequent. There are also other fragments which could serve as examples here, for instance when the same character does not hesitate to declare his love to Duchess Elisabetta, which probably also was the form of courtly game. ${ }^{27}$ As much as seemingly daring and unembarrassed Aretino's declarations could be seen as the conventions of courtly behaviour, his words: 'No (quoth he) speake you not (madam) for it is not your turne to speake nowe, ${ }^{28}$ seem to verify the thesis that Castiglione's aim was to present the Duchess as a person seeking to reduce the distance between her and her interlocutors in order that it does not determine her relations with these people.

We have reasons to assume that similar relations should determine the group at Prądnik, especially when Górnicki describes Bishop Maciejowski as full of open cordiality to his courtiers 'with whom he lived not like a lord with his servants but like a father with his sons. ${ }^{29}$ This openness of the Bishop, however, is of quite different character than that of the Duchess. Maciejowski seems to be quite a despotic 'father.' It is suggested by the fact that the word which is most often used to describe the Bishop is a verb 'to order' (pp. 28, 30, 294, 501). Maciejowski's authoritativeness is also evident in the moment of choosing the first game. The persons present ask the Bishop to indicate someone who has

26 Castiglione, Book of the Courtier, p. 38 ('Io - disse - vorrei esser giudice con autorita' di poter con ogni sorte di tormento investigar di saper il vero da' malfattori; e questo per scoprir gl'inganni d'una ingrata, la quai, con occhi d'angelo e cor di serpente, mai non accorda la lingua con l'animo, [...] ne' se ritrova cosi' velenoso serpe nella Libia arenosa, che tanto sangue umano sia vago, quanto questa falsa.' p. 30).

27 Ibid., p. 274: '[...] bicause love was never taught me, but by the divine beawty and most divine maners of a Lady, so that it was not in my will not to woorshippe her [...]' ('[...] lo amare a me non fu mai insegnato, se non dalla divina bellezza e divinissimi costumi d'una Signora, talmente che nell'arbitrio mio non e stato il non adorarla.' p. 336).

28 Ibid., p. 30 ('Non parlate, signora, che non è il vostro loco di parlare.' p. 31).

29 Górnicki, Dworzanin polski, p. 22. 
to propose the first game, ${ }^{30}$ since, as they explain, they would not be able to decide unanimously. Some time later, they again ask the Bishop to establish the order of their talks. ${ }^{31}$

Indeed, Maciejowski does not distance himself from this idea and arranges the order of their turns: Sir Wapowski was indicated as the next one after Kostka, and then Sir Myszkowski, next Sir Derśniak, Bojanowski and Sir Kryski at the and. ${ }^{32}$

In the Italian text, however, the interlocutors - seated around a round table - propose to play in the same order they are sitting at the table. Thus, the situation presented in the Cortegiano is socially unique, the play overcomes the social hierarchy (even if only apparently).

The court at Urbino is a place where social differences remain in the sphere of conjectures, at that moment of the play all are at the same social level. For this reason Gaspar Pallavicin, discontented with the fact that he is the first to speak, tries to release himself from this duty. And only after the inference of Duchess Elisabetta he agrees to present his proposal, but not without emphasising that he does not fully accept the decision of the duchess:

It is surely a great matter [...] that it is alwaies lawfull for women to have this privilege, to be exempt and free from paines takyng, and truely reason woulde we should in any wise knowe why. But bicause I will not be he that shall geve example to disobey, I shal leave thys untill an other time, and will speake of that I am nowe charged withall, and thus I beginne. ${ }^{33}$

This situation has not its counterpart in the Polish version. In Górnicki's text the Bishop (still present) chooses one of the debaters, Sir Kostka, to be the first to speak:

A ty, Kostka, nie mnimaj, iżemci przodkować kazał, abych ciebie za najmędrszego rozumiał, ale dla tegom to uczynił, abyś nie musiał na zad zostawszy, nic nie

\section{Ibid., p. 27.}

31 Ibid., p. 28.

32 Ibid.: '[...] tedy panie Wapowski, WM. rozkazuję, abyś wnet po Kostce grę swoję powiedział, a po WM. pan Myszkowski, potym pan Derśniak, więc pan Bojanowski swoję wynajdzie, a pan Kryski zostanie na ostatek.'

33 Castiglione, Book of the Courtier, p. 35 ('Gran cosa è [...] che sempre alle donne sia licito aver questa essenzion di fatiche, e certo ragion saria volerne in ogni modo intender la cagion; ma, per non essere io quello che dia principio a disobedire, lassero questo ad un altro tempo, e diro quello che mi tocca.' p. 27). 
powiedzieć, jako się to więc tym trefla, którzy dostatek rzeczy w głowie swej nie mają. ${ }^{34} 35^{*}$

It is true that Maciejowski speaks to his young courtier like a father to his son: straightforwardly and frankly. On the other hand, his tone is categorically and imperious (maybe even with a note of malice). At the same time we have to bear in mind that also his guests prefer to submit themselves to his authority. The Bishop himself at the beginning of the conversation makes a clear distinction between his own courtiers and those at the royal court:

Powiedział zasię ksiądz biskup [...] tobie [Kostka] to rozkazuję, abyś począł a swoją grę wynalazł, a pana Kryskiego, pana Wapowskiego, pana Myszkowskiego, pana Derśniaka, pana Bojanowskiego proszę, aby toż uczynili. ${ }^{367^{*}}$

Even if the time at which the dialogue takes place is the leisure time of otium, the personal relations at Prądnik are hierarchised in a specific way. The game, unlike in the Cortegiano, does not serve as a pretext to forget social differences between the participants. What is more, they try to emphasise these differences. Thus, in the Polish text the otium does not create a different world which would be in the opposition to the real one. Górnicki is consequent here: when political matters force the Bishop to leave the company, he appoints his brother Stanisław Maciejowski, as his deputy, ordering him that everyone be obedient to his will. ${ }^{38}$ (It is not an original idea of Górnicki, also in the Italian text the duchess, although she was present all the time, handed over her power to Lady Emilia Pio.)

Having in mind the Bishop's words, the other dialogists address the Castellan with great esteem, while he seems to be a person enjoying very much the function of the organiser of the meeting his brother entrusted him with, for he reminds many a time:

34 Górnicki, Dworzanin polski, p. 29.

35 * And you, Kostka, don't suppose that I wanted you to be the first because I think you are the wisest, I did it because I didn't want you to stay behind and say nothing, like those who had empty heads.

36 Ibid., p. 28.

37 *And the Bishop said [...] I order you [Kostka] to begin and your play invent, and I ask Sir Kryski, Sir Wapowski, Sir Myszkowski, Sir Derśniak, Sir Bojanowski to do the same.

38 Ibid., p. 30 . 
Co tym ochotniej WM uczynisz, im to lepiej niż kto inny rozumiesz, jako wiele na posłuszeństwie należy, gdzie ma być porządek.

[...] przeto gdyż mnie tu jest zwirzchność zlecona, rozkazuję to WM., abyś około trefności mówił. ${ }^{39} 40^{*}$

Such conclusions could be drawn after comparing, for example, a request of the duchess in the analogous situation:

The Dutchesse answered: Tell us at least what he did.

\section{With a demand of Castellan of Lublin:}

Powiedział na to JMPan lubelski: Prawda ma zawdy miejsce, przeto panie Derśniaku, nie tylko komu inemu dla niej, ale i sobie byś WM. nie miał przepuszczać; wszakoż dozwalam tego WM, abyś osoby nie mianował, ale nam WM rzecz powiedz jako było. ${ }^{41} 42^{*}$

Also the way of formulating suggestions who would be the first to describe the ideal courtier perfectly evidences the difference in relations between the characters in the two texts. In the Dworzanin, Mr. Bojanowski (the author of the idea) addresses his words only to the Castellan, stressing that it should be him to decide who among the present will be given the task:

Widziałoby mi się, MPanie, abyś WM. obrał jednego z tych panów, a jemu to rozkazat, iżby opisał i wymalował słowy doskonałego dworzanina. ${ }^{43} 4^{*}$

Whereas in Castiglione's text, Octavian Fregoso addresses all the persons present:

39 Ibid., pp. 38, 197.

40 *And you will do it even more eagerly because you understand better than anyone that order much depends on obedience. [...] hence, for authority was given to me, I order you to speak to the point.

41 Ibid., p. 380; Castiglione, Book of the Courtier, p. 283 ('Rispose la signora Duchessa: Dite almeno cio che egli fece.' p. 346).

$42{ }^{*}$ And Castellan of Lublin said: The truth will always be, Sir Derśniak, not only for others but also for yourself, and for this reason I allow you not to appoint the person, but to tell us how it was.

43 Górnicki, Dworzanin polski, p. 37.

$44{ }^{*}$ I would like you, sir, to choose one of these sirs, and order him to describe and paint with words the perfect courtier. 
I would have suche a pastime for this night, that one of the company myght bee pisked out who should take in hand to shape in woordes a good Courtyer [...]. ${ }^{45}$

The Castellan's decisions, like decisions of the Bishop, are accepted by the present without reservations. It is evident, for example, in the reaction of Sir Kryski, whom the Castellan of Lublin instructs to describe and paint with words the perfect courtier:

Zrzucić go [postanowienia pana lubelskiego] z siebie ani mogę, ani chcę, abych sie nie sprzeciwił wolej WM. ani ubliżył zdania rozsądkowi jego, który wiele stopni niż mój wyższy. ${ }^{46} 47^{*}$

The rule of 'absolute subjection' does not apply to the Italian text. Insofar as Canossa, like Kryski, accepts with no reservations Lady Emilia's decision, when she designates him as the first speaker, someone else, when asked by the 'locotenente' to speak, at all costs tries to release himself from this duty: 'But first (madam) you must beeginne to propounde yours. ${ }^{4} 8$ The introduction of different characters, members of analogous social circles, but not of the same culture, implies the change in character of their mutual relations. It seems as if at Prądnik there is no naturalness: what is here in the first place is a distance, the author constantly reminds about the hierarchy at the court and postulates behaviours which will follow clear rules. Each of the interlocutors seems to perfectly know and accept his role and position within the group, whereas the atmosphere at the court in Urbino is characterised by a certain intimacy, warm and agreeable. But it is just smoke and mirrors, because even if in the Cortegiano the group of the people present is more numerous than in the Dworzanin, the real participants in the discussion are only the characters being literary representations of those persons who played important part in the political or cultural life of $16^{\text {th }}$-century Italy. The others listen to the conversation in silence, only sporadically speaking out. These are most often figures contrasting with a sophisticated elegance and lofti-

45 Castiglione, Book of the Courtier, p. 41-42 ('Vorrei ch'l gioco di questa sera fusse tale che si elegesse uno della compagnia e a questo di desse carico di formar con parole un perfetto cortegiano.' p. 36).

46 Górnicki, Dworzanin polski, p. 39.

$47{ }^{*}$ Neither I can nor want to reject it [Castellan of Lublin's resolution] in order not to stand against your will, sir, nor offend your reason which is much better than mine. 48 Castiglione, Book of the Courtier, p. 35 ('A voi tocca, signora, dir prima il vostro.' p. 27). 
ness, injecting elements of coarse humour. The specificity of their role is evident at the beginning of the text, when one of those characters, frier Seraphin, proposes a game with erotic undertones. His words lower the tone of the discussion and this causes and immediate reaction of Lady Emilia, who interrupts frier Seraphin and ask Unico Aretino to speak. This behaviour of the 'locotenente' indicates a specific position of the jester among the gathered people, which means that even if he can speak, his words are censored. Some people begin speaking only after they are prompted by Lady Emilia, like in the case of sculptor Johnchristopher Romano. The difference between the Italian and Polish patterns of behaviour is that in Castiglione the hierarchy is hidden in the atmosphere of cordiality, entertainment and jokes; all the present persons accept it and only make the impression that it does not exist. Górnicki, on the other hand, rejects this solution and constructs his dialogue in such a way as to reveal the hierarchised relations between the persons gathered at the Bishop's court. This move, however, results in blurring in the Polish text of the main themes of the Italian origin - sprezzatura, that is the impression of effortlessness. ${ }^{49}$

This different presentation by Górnicki both of the picture of the court itself and the picture of the society rises a question whether also the way of presenting and exchanging opinions by the Polish interlocutors differ from the model of conversation offered in the Italian model. We should bear in mind that the subject of the conversation seems to be as much important for the Polish author as for Castiglione; in the Book Two of both texts there is a discussion about the ideal courtier's skill of conversation (pp. 179 and 192-193 accordingly) and Górnicki translates this fragment very faithfully. Conversation is presented as a real strategy and only the use of all its rules can guarantee success.

The first danger to appear in the both texts is the possibility for the conversation to be dominated by the person who is speaking at the time (the persons whose social position is higher than the other people gathered there do not participate directly in the game, but are responsible

49 Górnicki, Dworzanin polski, p. 69 ('a to [...] jest, aby człowiek tak z mową, jako i z sprawami namniej się nie wydwarzał, jedno niedbale jakoś a wrzkomo tego sobie nie mając nizacz wszystko czynił’). 
for organising discussion) and for this reason all is done to stifle this possible 'hegemony.' In the Cortegiano, when Lady Emilia says to Lewis Count of Canossa to be the first one present the ideal courtiers, she justifies her decision:

[...] you (Count) shall be he that shall take this enterprise uppon hym [...]. Not for that we knowe ye are so good a Courtyer that you have at your fingers endes that belongeth thereto: but because in repeatinge everye arsiversy, as we hope ye wyll, we shall have somuch the more pastyme..$^{50}$

Thus, she is belittling the abilities of the speaker in order not to let him dominate over the group and at the same time skilfully introducing an element of game into the conversation. Also the Castellan of Lublin, when indicating Sir Kryski as the first one to speak, tries to justify his choice, telling the group that not all of them have their say, for there is still Sir Kryski, who has not said his story. And he will almost certainly tell a different type of story. In this way, he will pay off what he owes: he has to describe and paint with words the perfect courtier. And he will do it even more willingly than others, because he better than other understands how important is obedience where there shall be order:

Mnie by się ta gra barzo podobała, ale mi idzie o to, żeście sie WM. jeszcze nie
wszyscy wyprawili: został pan Kryski, który nie powiedział gry swojej. A jeśli
ja dobrze znam postawę jego widzi mi się, że nam miał coś osobnego a nad to,
co się tu mówiło, powiedzieć. Wszakże to będzie na to lekarstwo: co był winien
pan Kryski, to tu w tym zapłaci; weźmiesz to WM. na się, panie Kryski, opisać
i wymalować słowy doskonałego dworzanina. Co tym ochotniej WM. uczynisz,
im to lepiej niż kto iny rozumiesz, jako wiele na posłuszeństwie należy, gdzie
ma być porządek. ${ }^{51}$

Thus, in the both cases emphasis is put on the fact that chosen persons are not experts in the field they are about to talk about, so they are not better than the others. At the same time even the speakers themselves try to depreciate their own abilities to soothe the impression of their authoritative domination:

50 Castiglione, Book of the Courtier, p. 42 ('[...] voi, conte, sarete quello che averà questa impresa $[\ldots]$ non già perché ci paia che voi siate cosi bon cortegiano che sappiate che si gli convenga, ma perché, dicendo ogni cosa al contrario, come speramo farete, il gioco sarà più bello.' p. 36).

51 Górnicki, Dworzanin polski, p. 38. 
The Count aunswered by and by [...]. But truely I would with all my hearte bee ridde of this burthen, for it is to hard for me. And I know that to be most true in me which you have spoken in jest: namelye, that I have no understandynge in that belongeth to a good Courtyer. ${ }^{52}$ (C.)

Pan Kryski na on czas tak odpowiedział: - I gry żadnej, MPanie, trefniejszej w mej głowie nie było, i z tego zaprawdę rad bym jakkolwiek zniknął, a to dlatego iż widzę być rzecz zbytnie trudną, ani ja najduję tego baczenia w sobie, żebym wiedział, co prawemu dworzaninowi należy. ${ }^{53}(\mathrm{G} .)^{54^{*}}$

In the same way act all those who are asked to comment on the questions arising during the conversation. On the one hand, such an attitude could be regarded as the manifestation of a topical captatio benevolenliae, while on the other, objections of the interlocutors 'demonologise' the dialogue. Nobody wants to appear more competent than others. Since the communication is to a large extent 'one-way', which results from the fact that the speeches are rather long, there is a real risk of losing a balance of dialogue. By minimising their skills and abilities, the interlocutors are increasing the value of the group; they speak only after explaining that they do it not to be accused of disobedience. ${ }^{55}$ In addition, there was a rule introduced at the very beginning of the conversation which allows to oppose an opinion of others:

[...] w tych rzeczach, które będą się zdały zdrożne a nieprzystałe dworzaninowi. (G.) $)^{56^{*}}$

And in suche thinges as shall not appere necessarie, as of necessitie must be in hym that deserveth against them $\left[\ldots . .{ }^{57}\right.$ (C.)

This rule serves also to emphasise the equality of the members of the group, and at the same time it makes it possible to paint an image of the

52 Castiglione, Book of the Courtier, pp. 42-43 ('Subito rispose il Conte: - [...] $\mathrm{Ma}$ io veramente, Signora, molto volentieri fuggirei questa fatica, parendomi troppo difficile e conoscendo in me cio che voi avete per burla detto esser verissimo, cioè ch'io non sappia quello che a bon cortegian si conviene.' p. 37).

53 Górnicki, Dworzanin polski, p. 39.

$54{ }^{*}$ And Sir Kryski said at the moment: - and no other game, Sir, was better in my head, and for this reason I would be glad to disappear, because I see this task too difficult for me and I have no idea what belongs to a good courtier.

55 Cf. A. Paternoster, 'Il teatro della retorica non-apparente. La struttura del dialogo nel Cortegiano', Lingua e stile, 26, 1991, p. 51.

$56{ }^{*}[\ldots]$ in such things which shall appear indecent and improper to the courtier.

57 Górnicki, p. 38; Castiglione, Book of the Courtier, p. 42 ('in quelle cose che non pareranno convenienti [...].' p. 36). 
perfect courtier not for one person but for the whole group. The 'verbal portrait' of the ideal courtier is thus a dynamic, changing picture which is created as a result of clashing opinions and convictions. This makes the final image of the perfect courtier more probable.

Thus, the participants of the conversation are allowed to intervene and in fact they often exercise this right. In such moments Górnicki tries to follow the Italian original very faithfully: when one of his characters speaks to comment what someone else said, he employs commonly accepted rhetorical and argumentative schemes used by Castiglione. ${ }^{58}$ The speaker, making use of them, indicates his will to cooperate. His comment could be defined as ad rem criticism, ${ }^{59}$ and thus the opinion of others are respected. There is also another element characteristic of the court at Urbino which Górnicki derives from Castiglione's text: a naturalness of characters commenting words of their predecessors:

Prze Pana Boga, daj im WM. za wygrane, bo widzę, iż mało sprawisz swą odpowiedzią [...]. (G. $)^{60^{*}}$

Tushe, for love of God (quoth he) graunt him the victory, for I know ye shall do small good $[\ldots] \cdot{ }^{61}$ (C.)

This device fulfils a concrete artistic function - it has to soothe a didactic tone of the both texts. Naturalness expresses itself also in personal allusions:

Jedno, panie Derśniaku, masz WM. te sławę, jakobyś na wielu miejscach zaraz miłować miał. (G.) $)^{62^{*}}$

58 For this reason it is very often that in the Dworzanin, like in the Italian origin, antitheses are accompanied by different soothing techniques which turn the objections into a constructive feedback. Most often, the Polish author joins his antitheses with a condition, example, reference to experience or knowledge of general public, it is not uncommonly that antitheses are in the form of restrictions, consent or concession.

59 Cf. Paternoster, op. cit., p. 52.

$60{ }^{*}$ By God, sir, grant them the victory, for I see you will do small good with your answer $[\ldots]$.

61 Górnicki, p. 362; Castiglione, p. Book of the Courtier, p. 263 ('- Deh, per amor di Dio, - disse, - datigliela vinta, ch'io conosco che voi farete poco frutto [...].' p. 323; see also: Górnicki, p. 141: 'Odpowiedział pan Myszkowski: -A widzisz WM., panie Lupa [...]'; Castiglione, p. 120: 'Then laughed Syr Fridericke and said: Note M. Morello [...]'; ('Rise allor messer Federico, e disse: Vedete voi, signor Morello [...].' p. 140). $62{ }^{*}$ One thing, Sir Deresniak, you have this fame of loving in many places at once. 
For somuch as you are generallye most acceptable to women, it is a good likelihoode that you knowe al the waies how their good will is to be gotten. ${ }^{63}$ (C.)

What is important, however, is that Górnicki not only explains the allusions from the Italian text, but also adds some own. For example, when Sir Derśniak reminds the group Wapowski's adventure in Vilnius:

Powiedział zasię pan Derśniak: - Ba i onoć sie tu mało nie zydzie, coś WM., panie Bojanowski, o rozumie powiedział [...]. Jednak ja wiem, na kogoś to był WM. w ten czas przycią. ${ }^{64}$

It happens at the same time that the allusions added by Górnicki are regarded as a hidden attack, like during the discussion about playing cards. And as much as in the Italian origin Octavian Fregoso's words about card game do not excite the group so he turns to another topic, in the Polish text the same words said by Mr Myszkowski annoy $\mathrm{Mr}$ Kryski, who interprets them as an allusion to his stinginess:

Tu pan Kryski ścirpieć nie mógł, ale tak powiedziat: - Widzę, panie Myszkowski, iż tu WM. moje frasobliwą grę strofujesz i chcesz, aby ten frasunk ze skępstwa pochodzit. ${ }^{65}$

There are also in the Polish text, like in the Italian origin, sarcastic comments:

Tu pan Lupa powiedział: - Takowych dworzan dziś, panie Myszkowski, barzo wiele, boś tu WM. na krótce a włośnie pochlebcę chytrego wymalował.

- Dziwno mi - rzekł tu pan Bojanowski ze śmiechem - iż WM. białymgłowam nie każesz na sejm być posełkinami...

Tu przerwał pan Bojanowski, mówiąc: -A, bajkę to WM. poczynasz, panie Kostka, wierzę, że będzie długa. ${ }^{66} 67^{*}$

63 Ibid., p. 370; Castiglione, p. 275 ('Lo esser voi gratissimo universalmente alle donne è bono argumento [...],' p. 336); see also, Górnicki, p. 382: 'A chceszli WM., panie Derśniaku, prawdę powiedzieć, snadź się i WM. samemu i to, i owo nieraz przydało w miłości'; Castiglione, p. 283: 'And if you will tell the truth, perhappes it hath bine your chaunce to commit mo then one'; (' $[\ldots]$ e se volete dir il vero, forse che a voi talor e occorso farne piu d'una.' p. 347).

64 Górnicki, Dworzanin polski, p. 238.

65 Ibid., p. 173 (Here Sir Kryski could not stand it anymore, but said thus: - I can see, Sir Myszkowski that here you are rebuking my sorrowful game and you want this my worry to be born from stinginess).

66 Ibid., pp. 147, 303, 320.

67 "Here Sir Lupa said thus: - Today such courtiers, Sir Myszkowski, are in great numbers, for what you painted was a cunning flatterer. 
But sarcastic remarks in the Polish text are not as frequent as in the Cortegiano. In Castiglione, these comments are addressed also to the Duchess and Lady Emilia, whereas in the Dworzanin they are addressed only to the 'authors' of the perfect courtier. Therefore, in Górnicki's text these ironic remarks are the determinants of the equal social position: insofar as the relations between the Bishop and Castellan of Lublin on the one hand and the others on the other are characterised by a distinct hierarchic structure, there is no social distance between the others. What is more, often sarcastic comments which appear in the Polish text are much more intense than their Italian counterparts:

Odpowiedział na to pan Kostka: - Ba, to czysta: mężczyznami niechaj będzie wszystko czynić wolno, a wy, białegłowy, święcicami bąździe! Sprawiedliwe prawo zaprawdę, dziw, że go w Biblijej nie napisano! Ale, miły panie, powiedz mi to $[\ldots]$. (G. $)^{68^{*}}$

Then answered the L. Julian: Doubtlesse these be pretie argumentes that ye make, I merveile you put them not in writinge. But tell me $[\ldots] .{ }^{69}$ (C.)

Some other fragments of the Dworzanin are also marked with emotions which leads to an attack ad hominem instead of balanced Italian interactions:

Wtym pan Kostka rzekt: - Ja tego nie wycirpię, Miłościwy panie lubelski, abym chytrości pana Wapowskiego odkryć nie miał, który sprzysiągszy się (jako ja mnimam) tajemnie z panem Derśniakiem a z panem Bojanowskim przeciwko białymgłowain, we dwu rzeczach (moim widzeniem) barzo obłądzili. (G.) $)^{70^{*}}$ The L. Julian saide smilinge: Madam, I am so verie an ennemye to crafte and guile, that needes must I speake against the L. Octavian: who for that he is (as I muche doubt him) a secrete conspiratour with the L. Gaspar againste women,

- It's strange - Sir Bojanowski said laughingly - that you, sir, don't want ladies to be deputies of the parliament...

Here Sir Bojanowski interrupted, saying: - Well, now it's your turn to tell a tale, Sir Kostka, and I believe it will be a long one.

$68{ }^{*}$ Then answered Sir Kostka: - Certes, men are free to do whatever they want, while you, women, have to be saints! Indeed, this is a just law, the wonder is that it has not been inscribed into the Bible! But tell me, dear sir...

69 Ibid., p. 338; Castiglione, Book of the Courtier, p. 249 ('Allora il Magnifico, Questi, rispose - veramente sono belli argumenti che voi fate e non so perché non gli mettiate per iscritto. Ma ditemi [...].' p. 305).

70 * Then sir Kostka sais: - I will not stand it anymore, Sir Castellan, not to reveal a cunning plot of Sir Wapowski, who conspires (as I suppose) secretly with Sirs Derśniak and Bojanowski against women, and committed error in two things (in my opinion). 
hath overshott himselfe in committing of two errours (in mine opinion) very great. $^{71}$ (C.)

The Polish version in the quoted fragments seems to be faithful to the Italian original but it is only false appearance, since small changes proposed by Górnicki totally change the tone the Polish statements. The adverb 'smilinge', which gives a humorous tone to the words of Julian de Medicis, disappears. What is more, there appear such expressions as 'nie wycirpię' (I can't stand it anymore) and 'chytrości' (cunnings), which emphasise the emotional engagement of Sir Kostka. After the modifications of the Polish author the words of the Pole are not Italian banter, but they become a real attack, which is not softened even by the terms indicating the subjectivity of opinions. ${ }^{72}$ Apart from this type of modifications, there could be seen another difference between the Italian and Polish versions: often, contrary to the Cortegiano, the dialogues of the Dworzanin contain words characteristic of the colloquial language. Occasionally, there are whole sentences which replace the original Italian ones.

Powiedział pan Myszkowski: - Z grubym a ze znacznym błażeństwem wyjechałeś tu WM. na plac $[\ldots]]^{73^{*}}(\mathrm{G}$.)

Me think (M. Unico) quoth Sir Friderick then, ye harpe to muche uppon your extremities. ${ }^{74}$ (C.)

Yet, equally often it happens that they take on the form of expressions added to the translated Italian sentences:

Odpowiedział pan Kryski: - Nie wchodź WM. ze mna w te gadkę, boć WM. daleko zawiodę, abowiem szerokie pole mam chwalić muzykę [...]. (G.) $)^{75^{*}}$

71 Górnicki, Dworzanin polski, p. 461; Castiglione, Book of the Courtier, p. 334 ('Disse ridendo il Magnifico Iuliano: - Signora, io son tanto nemico degli inganni, che m’e forza contradir al signor Ottaviano, il quale per esser, come io dubito, conglurato secretamente col signor Gaspar contro le donne, è incorso in dui errori, secondo me grandissimi.' $p$. 405). 72 Analogically, pp. 265 and 303, 244 and 285, 459 and 403, 342 and 308.

73 * Said Sir Myszkowski: - You have made a fat and big tomfoolery here, sir [...].

74 Górnicki, Dworzanin polski, p. 128; Castiglione, Book of the Courtier, p. 110 ('- A me par, signor Unico, - disse quivi messer Federico, - che voi andiate troppo in su le estremità.' p. 126).

75 *Answered Sir Kryski: - Do not, sir, enter into this chat with me, for I shall disappoint you very much, since I have a broad field of the praise of music [...] 
Speake it not, answered the Count. For I shall enter into a large sea of the praise of Musicke $[\ldots] .^{76}(\mathrm{C}$.)

Or the whole added sentences:

Jeślim ja dobrze baczył, panie Wapowski, zda mi sie, iżeś WM. potwirdził tego panu Kostce, iż powścięgliwość nie jest prawie doskonała cnota, a to tym, że ma w sobie nieco żądzej. O czym wole z WM. niż z panem Kostka mówić.

Tu rzekł pan Lupa: - Cóżeś to zaś, WMPanie Wapowski, za kontemplacyją na króla wyrwał?77 $78^{*}$

Thus, it could be said that the rhetorical techniques serving to soften the antitheses are inserted in the Polish version in all these places where the text is a faithful translation of the Cortegiano and in such cases a critique of the interlocutors does not exceed the boundaries of ad rem attack. On the other hand, when Górnicki strays away from the Italian origin, his interlocutors become very emotional, and their conversation turns to the vernacular, thus gaining spontaneity and naturalness. These spontaneity and naturalness are also present in the Italian version, but they seem to perform the function of a veil under which there is always a controlled elegance and sophistication of expressions. For this reason, the Italian original, contrary to the Polish text, is never naturalistic and the balance of interaction is never upset. And also for this reason the competition between the members of the group ceases to be pronounced. The Italian interlocutors always discuss in such a way as to pay respect to others, according to the rule that the more they hide their intentions to beat their rivals, the easier it will be for them to gain the approval for their own opinions. ${ }^{79}$ In the Polish text, where the dialogues are less stylised and less theatrical, this rivalry is much more pronounced, which upsets the harmony between the heuristic and eristic weight. Thus, the technique

76 Górnicki, Dworzanin polski, p. 108; Castiglione, Book of the Courtier, p. 89 ('Non dite, - rispose il Conte; - perch'io v'entrar è in un gran pelago di laude della musica.' p. 100).

77 Górnicki, Dworzanin polski, pp. 416, 430.

78 * If I see rightly, Sir Wapowski, it seems to me that you, sir, agreed with Sir Kostka that discretion is not almost perfect virtue, for its contains a grain of lust. But I prefer to speak about it with you than Sir Kostka.

Here sir Lupa said: What was your contemplation, Sir Wapowski, that you said about the king?

79 Paternoster, op. cit., p. 50. 
of 'persuasion of non-persuasion,' ${ }^{80}$ characteristic of Castiglione's text, is lost. If, then, the purpose of the both authors is to present "what belongeth to the perfection of Courtiership," in the Cortegiano - contrary to the Dworzanin - he hast to be created with a perfection of words and model ways of conversation. This perfection, however, does not contain any traces of artificiality, but rather results from a simulated casualness and spontaneity, according to the rule being the leading motif of the text, ordering to avoid evident affectation. Sprezzatura then seems to organise a dialogue presented in the Cortegiano, and the changes introduced by the Polish author modify this intention. Similarly, sprezzatura in the Italian text shapes the relationship between the 'authors' of the perfect courtier and their superiors: the hierarchic structure in Urbino is veiled by humorous elements and freedom of speech, but they never lead to excessive familiarity. Górnicki's modifications, on the other hand, demonstrate this hierarchy of relations, so also this aspect loses its value in the Polish text. In one word, the changes introduced by the Polish author only apparently seem to be of no significance, in actual fact they eclipse the sophisticated and harmonious architecture of the Cortegiano. Sprezzatura - invented by Castiglione - which could be defined as a social technique and which should determine the attitude of the courtier, in the Polish text is only a concept being the subject of discussion (Book Two); but it is not allowed to shape the life at Górnicki's court in Prądnik.

\section{Translated by Grażyna Waluga}

First published as: 'Urbino i Prądnik: dwa dwory, dwa światy', Odrodzenie i Reformacja $w$ Polsce, 45, 2001, pp. 45-61.

80 Ibid., p. 51: 'di una persuasione della non persuasione'. 